\title{
Robert D. Tollison, 65 years on
}

\author{
William F. Shughart II
}

Received: 16 September 2009 / Accepted: 14 October 2009 / Published online: 27 October 2009

(C) Springer Science+Business Media, LLC 2009

Robert Tollison has been a major figure in the economics profession for 40 years, contributing a vast body of scholarship to the literatures of public choice, industrial organization, the economics of sports and the economics of religion to name just a few of the fields of study to which he has applied his fertile mind and the methodologies of positive economic science. Perhaps more than any other person, he conceived and fostered the development of empirical public choice. What is perhaps more important, over a distinguished career that began - freshly conferred University of Virginia Ph.D. in hand-with his appointment to the Cornell University business school faculty in 1969, included two tours of duty in Washington, DC (at the Council of Economic Advisers early on and, later, at the Federal Trade Commission) and wound its way through the halls of academe at College Station, Miami, Blacksburg, Clemson, Fairfax, Oxford, and then back to Clemson, Bob has engaged generations of students and colleagues in his research program, generously sharing ideas, insisting on getting those ideas down on paper and in the process not only launching or advancing the careers of many other scholars, but also forging lifelong friendships.

A small subset of those friends gathered in Clemson, South Carolina, on November 6-8, 2007, to celebrate Bob's 65th birthday and to participate in a conference honoring his life and work. Sponsored by Clemson University's John E. Walker Department of Economics, the conference's organizers commissioned a series of original research papers for presentation and discussion over the course of the event's two-day working schedule.

This special issue of Public Choice compiles those papers and the comments on them written by invited discussants. Despite Bob's wide-ranging research interests, Public Choice is the proper place for recognizing his scholarship. As a student of Nobel laureate James Buchanan, no man has done as much as he has done to advance the public choice research program. Bob was for many years a member of the faculty of the Center for Study of Public Choice when it was housed at Virginia Tech and, after the Center had moved to George Mason University, served as its Director.

W.F. Shughart II ( $₫)$

Department of Economics, University of Mississippi, P.O. Box 1848, University, MS 38677-1848, USA

e-mail: SHUGHART@olemiss.edu 
As a rule, the volume follows the conference's format, which consisted of seven panels, each for the most part consisting of two papers on topics related to the principal areas of the literature to which Bob has made-and continues to make-significant contributions. With only a few minor exceptions, the original research papers are paired with their corresponding written commentaries. Although the articles published herein were not subjected to a formal refereeing process, all withstood careful editorial scrutiny both as to substantive content and expository lucidity.

The conference opened with a session devoted to empirical public choice. The first of the papers, by Mark Crain and Nicole Crain, uses empirical methods to explore the properties of the time series of Bob Tollison's writings, testing the influences on his scholarly productivity of, among other things, his academic affiliations and his taste for co-authorship. The Crain and Crain paper speaks for itself and, hence, is one of the few contributions to the volume that did not seem to call for written commentary. Brian Goff comes next, with a typical Tollisonian examination of the impact of the educational backgrounds and prior employment histories of presidential economic advisers on economic policy outcomes. He finds, as Bob Tollison frequently has observed, that ideas may matter, but not much. The exception is non-defense federal spending, where budget outlays tend to be higher when a president's economic advisers had been trained or employed by an Ivy League institution prior to their governmental service. However, Goff also finds the significance of that influence to differ according to presidential administration, possibly implying that presidents select their economic advisers to provide the advice they want to hear rather than for independent analysis of policy proposals.

Session two focused on the economics of sports, or what Bob has called sportometrics. The papers presented then, one by Raymond Sauer, Kerry Waller and Jahn Hakes, the other by Robert McCormick (with Tollison as co-author), demonstrate the importance of the insights into economic behavior that can be gained by stepping outside the boundaries of ordinary markets into the wide world of sports-Major League Baseball in the first case and the game of golf in the second. Are (betting) markets efficient? Perhaps, as Sauer et al. ultimately conclude. Why, holding other things including gender differences in muscle strength constant, are women's tees closer to the pin than men's tees? And can the differences in tee placement, which differ systematically between courses in the South and in the North, be explained by chivalry? That is one implication of the McCormick-Tollison contribution, based on a rich dataset covering more than 15,000 golf courses in all 50 US states.

Bob Tollison was influenced strongly by George Stigler's work on the economic theory of regulation and that was the topic that ended the conference's first morning of work. Bruce Yandle's paper discusses the decline in economic regulation and the explosive growth in social regulation that began in the United States during the 1970s—events that also shifted regulatory enforcement from the realm of the common law to that of legislatively enacted statute law-and attributes those developments to the rise of national media markets and to a corresponding demand on the part of nationally operating businesses for federal as opposed to state-level regulation. Richard Higgins and Arijit Mukerhee then presented a theoretical analysis of the deregulation of US telecommunications markets in the early 1980s, which mandated "vertical separation" between local and long-distance telephony. Their insightful analysis suggests that characterizing that policy initiative as "deregulation" is a misnomer. Separating local and long-distance markets actually complicated the regulatory process by forcing regulators to set the prices at which the providers of long-distance voice and data transmission services would be allowed to connect to (access) local customers. Access pricing arguably demanded more regulatory intervention than had been demanded when AT\&T merely was a vertically integrated "natural" monopoly. 
That session was followed by the presentation of three papers by students who at the time were (or had been enrolled) in Bob's undergraduate courses at Clemson. I have chosen to collect those papers, two on various aspects of sportometrics-by Herman Demmink III and by Adam Pope (in collaboration with Bob) - plus one on the economics of religion-by Anca Cojoc_-at the end of this special issue. No formal comments on those papers were invited, although all generated a great deal of interest from the conference's participants. The three undergraduate papers are published herein as a modest way of underscoring the point that Bob Tollison's contributions to the economics profession extend far beyond the limits of the doctoral dissertations he has supervised or those of the papers and books coauthored with graduate students and colleagues, past and present, he has inspired with his energy and enthusiasm for economics.

The Clemson conference's first day ended with a panel devoted to antitrust policy. The first of the two papers, by William Shughart and Fred McChesney, summarizes Bob Tollison's pioneering contributions to the literature of industrial organization, which emphasize the influence of special-interest groups on the antitrust law enforcement process. Prior to Bob's appointment as Director of the Federal Trade Commission's Bureau of Economics by James C. Miller III, his contemporary as a graduate student at the University of Virginia, antitrust's "failures" were obvious. But only Bob Tollison saw that those failures could be explained by applying public choice and interest-group theory reasoning to the law-enforcement data. Shughart and McChesney's paper documents Bob's work and that of his colleagues in this important policy area. Andrew Young and William Shughart then supply new empirical evidence, from a macroeconomic perspective, that supports his basic insight, namely that antitrust policy is not about protecting the interests of consumers. At best, the effects of antitrust law enforcement on the macro-economy are merely transitory, hardly justifying a vigorous and costly-to-maintain antirust regime.

The final (half-day) of the conference was devoted to the presentation of two papers, both co-authored by Robert Ekelund, Jr. and Robert Hébert, which recapitulated Bob Tollison's contributions to the economics of religion and to the history of economics. The "three Bobs" have collaborated on numerous journal articles and books that study, from positive economics and public choice perspectives, the evolution of the industrial organization of the Catholic Church and its doctrines, the causes and consequences of the Protestant Reformation and pre-Smithian Mercantilism and other important episodes in economic history, especially as they relate to the origins and actual effects of economic regulation. Separately, Bob has collaborated on numerous papers that, inter alia, inquire into the citation practices of economists and the durability of their contributions to the existing literature. Ekelund and Hébert summarize these contributions ably; their two essays also ought to inspire other scholars to follow Bob Tollison's lead.

It is impossible, in these brief introductory remarks, adequately to convey to this special issue's readers what Bob Tollison fully means to his many hundreds (thousands?) of students and colleagues. Bob would have had a successful academic career if he had gone it alone, as many economists do. (Well, perhaps not. To my knowledge he has not run a regression since graduate school.) Unselfishness is what distinguishes Bob's place in the economics profession. Partly that is because he has many more ideas than any one human being conceivably could bring to fruition in the pages of academic journals or of books. And so Bob (rationally) shares his ideas with others, most of whom are not as creative or as smart as he is, but because of their solid training in economic theory, econometric techniques, or both, are able to pursue them to publishable ends.

Bob Tollison was head (not "chairperson") of the economics department at Texas A\&M when I was a graduate student there in the late 1970s. I (unfortunately) never took a course 
from him and except for his bumming of cigarettes from me and from my late and much missed officemate Dave Saurman had little contact with him then (Bob announced his intentions in the hallway on the way to our office by calling out "Tax Man”!). My fondest memory of Bob from graduate school days is from a very late night during a meeting of the Southern Economic Association in New Orleans (in 1977, I think) when he entered Jean Lafitte's French Quarter watering hole, where I and a few of my fellow students were enjoying a nightcap. I vividly remember Bob purposefully making a point of speaking to every Aggie there. That personal interest in the welfare of others to whom he was responsible, directly or indirectly, is Bob Tollison's defining characteristic and the reason that those who are fortunate to know him are so loyal. It is sometimes said of plowmen that they are like dwarfs standing on the shoulders of giants. There are many of us truly blessed to be standing on Bob's giant shoulders.

Keeping up a nearly continuous stream of journal articles and books would seem to have made Bob a dull boy. But he also always has had an impish streak. During his days at the Federal Trade Commission, Bob took great pleasure in parking his battered long-bed Dodge pickup truck in the underground garage at the commission's headquarters building at Sixth and Pennsylvania Avenue. He drove his fellow bureaucrats there crazy by displaying a bumper sticker supporting Ed Clark, then the Libertarian Party's candidate for president.

The conference at Clemson that resulted in this Festschrift left plenty of time for visiting with Bob's friends, his wife Anna, his son Mark Tollison and daughter April Kleinfeldt. In addition to the faculty and students of the John E. Waller Department of Economics, special thanks are due to April, Bobby McCormick, Skip Sauer, and Melissa Yeoh (then a Clemson graduate student and now an assistant professor of economics at Berry College) for all of the effort they invested in ensuring the conference's success.

Happy birthday, Bob Tollison, and many happy returns! 